\title{
Studies on increased vascular permeability in the pathogenesis of lesions of connective tissue diseases: I. Experimental hyperlipidaemia and immune arthropathy
}

\author{
A. J. VALENTE AND K. W. WALTON \\ From the Department of Investigative Pathology, Rheumatism Research Wing, The Medical School, University \\ of Birmingham, Birmingham B15 2TJ
}

SUMMARY In order to investigate the known associations between hyperlipidaemia and various rheumatic complaints, immune arthritis and hyperlipidaemia have been induced concurrently in rabbits. The results obtained show that: (1) Rabbit apolipoprotein B-containing lipoproteins (LpB), which are normally virtually excluded from joint fluid, gain access to the inflamed joint in the serous effusion and serve as intrinsic indicators of altered local permeability to macromolecules. (2) Much of the LpB entering the joint space is taken up by the phagocytic cells and, following intracellular hydrolysis, leaves a lipid residue. In some chronically affected joints these residues are modified so as to give rise to crystalline cholesterol and its esters. Such crystals may serve as chronic irritant in the joint. (3) In addition intact $\mathrm{LpB}$ is found sequestered in the superficial layers of intra-articular collagenous structures of the challenged joint in a distribution identical with that of similarly sequestered immune complexes and complement, suggesting altered permeability of these intra-articular structures also.

There are numerous reported associations between elevations of serum lipids or lipoproteins (hyperlipidaemia) and the occurrence of rheumatic complaints. ${ }^{12}$ Despite these associations very little has been done to explore a possible causal relation between hyperlipidaemia and joint disease apart from the proposal that crystalline cholesterol, derived from plasma lipids and deposited in the joints, may serve to give rise to one form of crystal arthropathy. ${ }^{3}$

This is an account of experiments involving the concurrent induction of an immune arthritis by the procedure of Dumonde and Glynn ${ }^{4}$ and hyperlipidaemia by cholesterol feeding in rabbits. The objectives of this work were: (i) to identify by immunological and immunohistological methods the source of origin of lipid deposited in joints; (ii) to examine the topographical relation of lipid or lipoprotein deposits to deposits of immune complexes in intra-articular structures; and (iii) to see whether the source and distribution of lipoprotein

Accepted for publication 1 November 1979 Correspondence to Professor K. W. Walton. in joint lesions allowed inferences to be made concerning the mechanism of production of the lesions.

Material and methods

Animals. Sixteen male New Zealand White rabbits, initially weighing $2-3 \mathrm{~kg}$, were obtained from Hyline Limited, Northwich, Cheshire. After an initial period of 2 weeks, during which all the animals were maintained on a standard basic diet (TR 2 pellets), $\frac{D}{0}$ they were divided into 2 equal groups. Group $A$ continued to be maintained on the standard diet, or while group B received a cholesterol-supplemented $N$ diet intermittently (see below).

Dietary Schedule. The cholesterol diet was pre- $\omega$ pared as previously described ${ }^{5}$ and administered to group B rabbits to coincide with the start of their $\stackrel{0}{=}$ period of immunisation. Cholesterol-coated pellets $\stackrel{\$}{\rightarrow}$ were fed until the mean serum cholesterol exceeded $900 \mathrm{mg} / 100 \mathrm{ml}$. The animals were then returned to 0 the normal diet, and the cholesterol-diet was re- $\overrightarrow{\mathbb{D}}$ introduced when mean serum cholesterol levels fell $\underset{\mathbb{D}}{\stackrel{\circ}{(}}$ below $600 \mathrm{mg} / 100 \mathrm{ml}$. Animals in this group were 
thus maintained at serum cholesterol levels between $265 \mathrm{mg}$ and $1200 \mathrm{mg} / 100 \mathrm{ml}$ for the duration of the experiment.

Total serum cholesterol was estimated twice weekly in group B animals by the method of Pearson et al. ${ }^{6}$

IMMUNOLOGICAL REAGENTS AND METHODS Antigen. Human fibrinogen was isolated from human Cohn fraction 1 essentially as described by Hawker and Hawker, ${ }^{7}$ and dialysed against saline-citrate buffer at $\mathrm{pH} 7 \cdot 2 \quad(0.9 \% \mathrm{NaCl}$ containing $1 \%$ trisodium citrate brought to $\mathrm{pH} 7 \cdot 2$ with $1 \mathrm{~N} \mathrm{HC1}$ ).

Immunisation of animals. Groups $\mathrm{A}$ and $\mathrm{B}$ animals were given an initial interscapular subcutaneous injection of $0.5 \mathrm{mg}$ human fibrinogen in Freund's complete adjuvant (FCA), followed 18 days later by $1.0 \mathrm{mg}$ of antigen in FCA divided into multiple subcutaneous injections administered to the flanks. Each rabbit was skin-tested 8 days later with $100 \mu \mathrm{g}$ of antigen in $0.1 \mathrm{ml}$ of buffer and the site examined 3,24 , and 48 hours later. All the animals showed positive skin reactions, and the presence of specific antibody in the serum was verified as described below.

Intra-articular challenge. Eleven days later $1 \mathrm{mg}$ of sterile human fibrinogen in $0.5 \mathrm{ml}$ of salinecitrate buffer was injected into the joint cavity of the right leg of each animal. The left joint received $0.5 \mathrm{ml}$ buffer as control. A second intra-articular injection ( $5 \mathrm{mg}$ fibrinogen in $0.5 \mathrm{ml}$ buffer) was given 13 days later.

Pairs of rabbits (1 each from group $A$ and group B) were killed with pentobarbitone sodium at 1, 4, and 10 days; $5,8,11,14$, and 36 weeks after the second intra-articular injection. Any synovial effusion present was recovered for examination. Synovial tissue, menisci, tendons, and ligaments from both knee joints were taken for histological and immunohistological examination. Smears of synovial fluid were fixed in alcohol and stained with Jenner-Giemsa stain, haematoxylin and eosin, or oil red $\mathrm{O}$ and light green. Wet preparations were also prepared for polarised light microscopy.

Assay of antihuman fibrinogen antibody was performed in a microtitration system with human fibrinogen coated on to sheep erythrocytes treated with bis-diazotised benzidine as described by Herbert. $^{8}$

Antiglobulin activity. Sera from rabbits of both groups were absorbed with normal sheep red cells and then tested for agglutinating activity against rabbit-IgG coated cells as in the usual Rose-Waaler test. $^{9}$

Immunohistological reagents. Antisera were prepared in guinea-pigs to the following rabbit serum proteins: (i) Rabbit $\beta_{1 \mathrm{c}} \beta_{1 \mathrm{a}}$ globulin prepared as described by Propp and Alper ${ }^{10}$; (ii) rabbit immunoglobulin $G$ (IgG) prepared on DEAE cellulose according to Stanworth ${ }^{11}$; (iii) rabbit low-density lipoprotein (LDL) as previously described. ${ }^{5}$ Antisera were raised in guinea-pigs by an immunisation schedule similar to that described above for human fibrinogen in rabbits. The antisera were shown to be monospecific by immunodiffusion. Fluorescent antibody conjugates were prepared as described by Nairn. ${ }^{12}$

Techniques of immunofluorescence. Direct immunofluorescence and conventional histology were carried out as previously detailed. ${ }^{5}$ The following indirect method was used to detect cells containing specific antihuman fibrinogen antibody: tissue sections were washed in phosphate-buffered saline (PBS) for 10 minutes, then incubated at room temperature with a solution of human fibrinogen $(3-4 \mathrm{mg} / \mathrm{ml}$ in saline citrate buffer) for 45 minutes. After a 20-minute wash in PBS the sections were treated with fluorescein-labelled rabbit-antihuman fibrinogen for 45 minutes, washed, and mounted in buffered glycerol. As controls, duplicate sections were processed as above but with saline-citrate buffer replacing the fibrinogen solution.

Synovial fluid analysis. For studies of the protein composition of rabbit synovial fluid, $300 \mu l$ of the fluid was incubated with $30 \mathrm{IU}$ of ovine hyaluronidase in $20 \mu \mathrm{l}$ saline for 1 hour. Insoluble material was removed by centrifugation and the clear supernatant fluid examined by 1- and 2-dimensional electroimmunodiffusion. ${ }^{13}$

\section{Results}

VALIDATION OF EXPERIMENTAL DESIGN Total serum cholesterol. The individual and mean total serum cholesterols for each group of the animals utilised are shown in Table 1. For the period of the experiment there was a highly significant difference $(P<0.001)$ between the mean cholesterol levels of the two groups.

Antibody response to human fibrinogen. Both groups of rabbits responded to the schedule of immunisation by producing high titres of antibody. Mean $\log _{10}$ reciprocal titres for a 12-week period from the first challenge with antigen are shown in Fig. 1. No significant difference in antifibrinogen antibody levels was encountered between animals of the two groups.

Production of immune arthritis. In confirmation of the observations of Dumonde and Glynn ${ }^{4}$ the antigen-injected joints of both groups of animals were found to become hot and swollen within 24 hours of first challenge. The severity and duration 
Table 1 Rabbit serum cholesterol concentrations. Means, standard deviations, and highest and lowest recorded values during the induction of the immune arthritis

\begin{tabular}{|c|c|c|c|c|c|c|c|c|c|}
\hline \multirow{3}{*}{$\begin{array}{l}\text { Group } \\
\text { A }\end{array}$} & \multirow{3}{*}{$\begin{array}{l}\text { Rabbit } \\
\\
1 \\
2 \\
3 \\
4 \\
5 \\
6 \\
7 \\
8\end{array}$} & \multicolumn{8}{|c|}{ Serum cholesterol $\mathrm{mg} / 100 \mathrm{ml}$ and $(\mathrm{mmol} / \mathrm{l})$} \\
\hline & & \multicolumn{2}{|c|}{ Mean } & \multicolumn{2}{|l|}{$S D$} & \multicolumn{2}{|l|}{ High } & \multicolumn{2}{|l|}{ Low } \\
\hline & & $\begin{array}{r}60 \\
77 \\
126 \\
55 \\
63 \\
68 \\
152 \\
86\end{array}$ & $\begin{array}{l}(1 \cdot 55) \\
(1 \cdot 99) \\
(3 \cdot 26) \\
(1 \cdot 42) \\
(1 \cdot 63) \\
(1 \cdot 76) \\
(3 \cdot 93) \\
(2 \cdot 22)\end{array}$ & $\begin{array}{l}13 \\
24 \\
65 \\
21 \\
20 \\
33 \\
42 \\
38\end{array}$ & $\begin{array}{l}(0.34) \\
(0.62) \\
(1.68) \\
(0.54) \\
(0.52) \\
(0.85) \\
(1.09) \\
(0.98)\end{array}$ & $\begin{array}{r}85 \\
115 \\
285 \\
110 \\
130 \\
165 \\
250 \\
150\end{array}$ & $\begin{array}{l}(2 \cdot 20) \\
(2 \cdot 97) \\
(7 \cdot 36) \\
(2 \cdot 84) \\
(3 \cdot 36) \\
(4 \cdot 26) \\
(6 \cdot 46) \\
(3 \cdot 88)\end{array}$ & $\begin{array}{l}45 \\
45 \\
50 \\
25 \\
35 \\
35 \\
85 \\
70\end{array}$ & $\begin{array}{l}(1 \cdot 16) \\
(1 \cdot 16) \\
(1 \cdot 29) \\
(0.65) \\
(0 \cdot 90) \\
(0 \cdot 90) \\
(2 \cdot 20) \\
(1 \cdot 81)\end{array}$ \\
\hline $\mathbf{B}$ & $\begin{array}{l}1 \\
2 \\
3 \\
4 \\
5 \\
6 \\
7 \\
8\end{array}$ & $\begin{array}{l}725 \\
655 \\
612 \\
721 \\
685 \\
815 \\
805 \\
800\end{array}$ & $\begin{array}{l}(18 \cdot 73) \\
(16 \cdot 93) \\
(15 \cdot 81) \\
(18 \cdot 63) \\
(17 \cdot 70) \\
(21 \cdot 06) \\
(20.80) \\
(20.67)\end{array}$ & $\begin{array}{l}407 \\
375 \\
346 \\
223 \\
187 \\
281 \\
269 \\
275\end{array}$ & $\begin{array}{r}(10 \cdot 52) \\
(9 \cdot 69) \\
(8 \cdot 94) \\
(5 \cdot 76) \\
(4 \cdot 83) \\
(7 \cdot 26) \\
(6 \cdot 93) \\
(7 \cdot 11)\end{array}$ & $\begin{array}{l}1200 \\
1080 \\
1070 \\
1075 \\
1000 \\
1170 \\
1190 \\
1050\end{array}$ & $\begin{array}{l}(31 \cdot 01) \\
(27 \cdot 91) \\
(27 \cdot 64) \\
(27 \cdot 78) \\
(25 \cdot 84) \\
(30 \cdot 23) \\
(30 \cdot 75) \\
(27 \cdot 13)\end{array}$ & $\begin{array}{l}300 \\
280 \\
265 \\
500 \\
435 \\
520 \\
465 \\
550\end{array}$ & $\begin{array}{r}(7 \cdot 75) \\
(7 \cdot 24) \\
(6 \cdot 85) \\
(12 \cdot 92) \\
(11 \cdot 24) \\
(13 \cdot 44) \\
(12 \cdot 02) \\
(14 \cdot 20)\end{array}$ \\
\hline
\end{tabular}

For the comparison of the mean serum cholesterol levels of groups $A$ and $B, t=20 \cdot 51, P<0.001$.

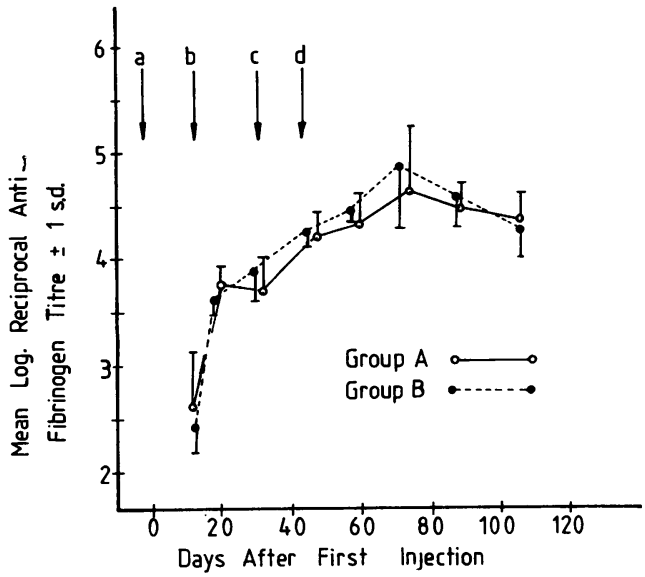

Fig. 1 Antihuman fibrinogen antibody response in group $A$ and $B$ rabbits. Fibrinogen injections: (a) $0.5 \mathrm{mg}$ in FCA, subcutaneous; (b) $1 \mathrm{mg}$ in FCA, subcutaneous; (c) $0.5 \mathrm{mg}$ in buffer, intra-articular; (d) $5 \mathrm{mg}$ in buffer, intra-articular

of inflammation varied between animals in each group irrespective of the dietary regimen. In all instances the saline-injected left knee joints showed no evidence of any inflammatory response. The affected joints of animals killed at various times showed oedema, marked hyperaemia, and villous hypertrophy of the synovial membrane and contained variable amounts of a viscous effusion. Pannus formation with infiltration of articular cartilage was seen during the latter half of the experiment.

Antiglobulin response. With one exception none of the rabbits in either group showed convincing evidence of the development of rheumatoid- factor-like antibody activity. The exception, a rabbit from group $B$, showed a steady increase in anti- $O$ globulin titre, which reached and maintained a level $\vec{\circ}$ of $1 / 64$ for 1 week before this animal was killed $\stackrel{\mathbb{Q}}{-}$ (Fig. 2). The antifibrinogen titre in this rabbit $\vec{\oplus}$ showed a steady decline over the same period.

\section{CHARACTERISTICS OF IMMUNE ARTHRITIS}

IN NORMAL AND LIPID-FED ANIMALS

Changes in synovial fluid. Stained smears made from fluids from the affected joints during the acute phase of the response showed the presence of several cell $\stackrel{\mathbb{Q}}{2}$ types. Polymorphonuclear granulocytes predomi- $\overrightarrow{\overrightarrow{0}}$ nated initially in fluids from both dietary groups. Lymphocytes monocytes, and occasional eosinophils were observed in later specimens. Large mononuclear cells, thought to be derived from the synovial membrane, were seen in variable numbers. These cells contained many cytoplasmic inclusions, among them

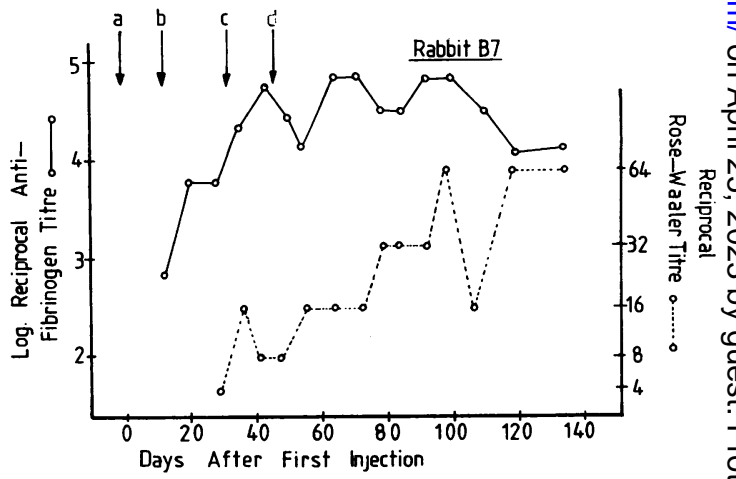

Fig. 2 Antibody and antiglobulin response in cholesterol fed rabbit B7. (a) to (d) as in Fig. 1 
large vacuoles containing ingested polymorphs in various stages of digestion (Fig. 3).

In smears stained with oil red $O$ the phagocytic cells from group A animals showed no evidence of intracellular lipid in addition to the inclusions described above. However, in smears from group B animals large numbers of lipid droplets were seen, which in some cases entirely filled the cell (Fig. 4). Much of the intracellular lipid showed the characteristic pattern of birefringence of cholesterol

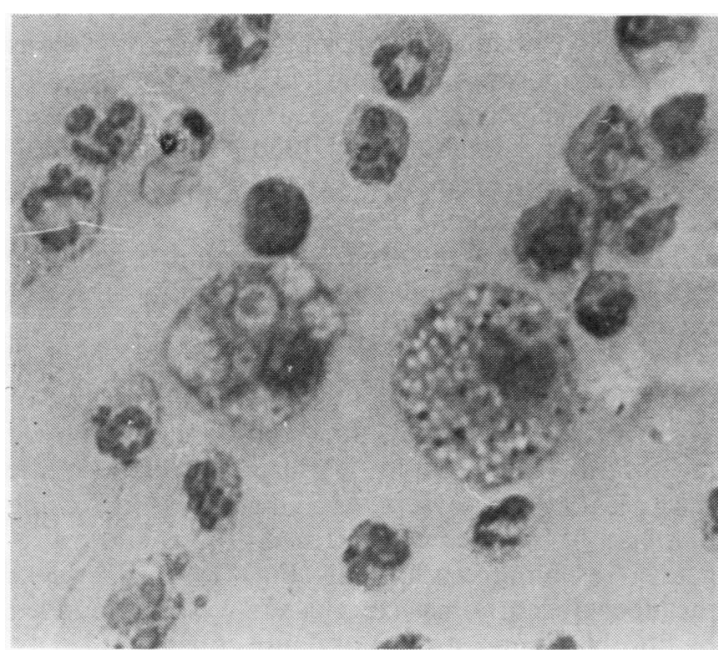

Fig. 3 Synovial effusion cells from a group A rabbit. (Jenner-Giemsa, $\times$ 500)

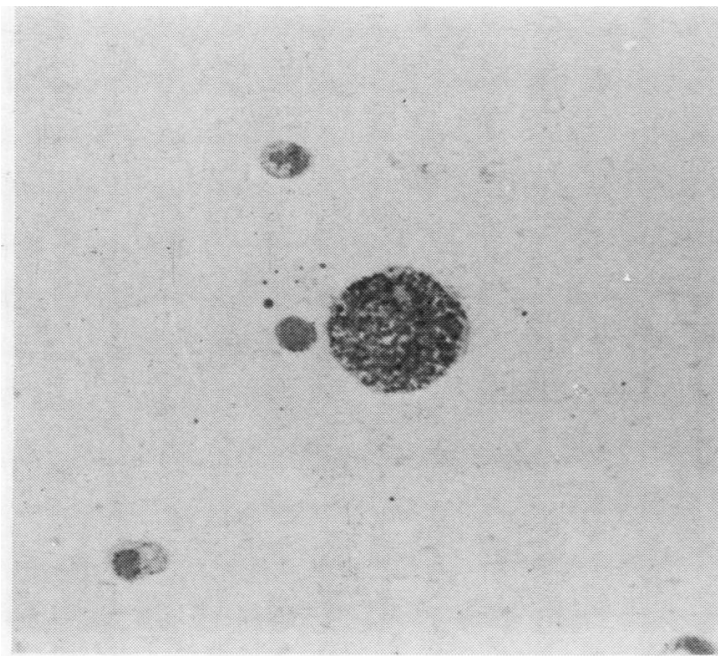

Fig. 4 Synovial effusion cells from a group $B$ rabbit (Oil red $O$ and light-green, $\times 500$ ) esters when viewed in polarised light (Fig. 5). Free cholesterol crystals were not seen in joint fluid from animals in which the arthritis has been present up to 14 weeks, but in the animal killed 9 months after the induction of hypercholesterolaemia and arthritis the typical brightly anisotropic notched plates of free crystalline cholesterol were seen (Fig. 6).

Two-dimensional electrophoresis of matched serum and synovial-fluid samples from affected

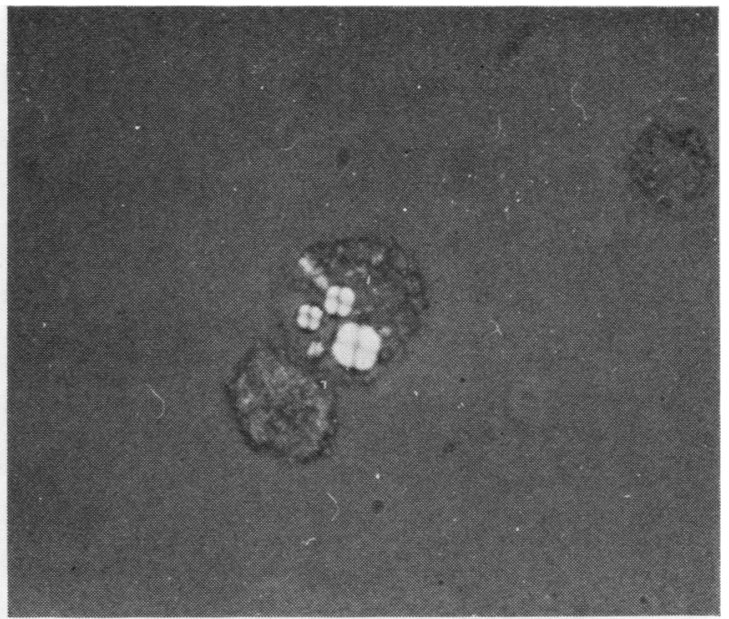

Fig. 5 Synovial effusion cells from a group B rabbit. Wet preparation viewed in polarised light $(\times 500)$.

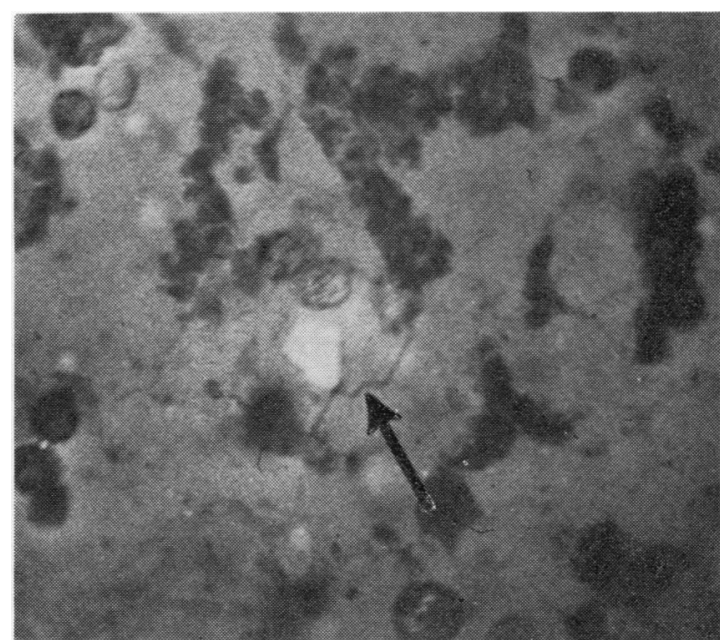

Fig. 6 Cholesterol crystal (arrowed) in the synovial effusion from a group $B$ rabbit taken 36 weeks after the last intra-articular injection. Wet preparation viewed in polarised light $(\times 500)$ 
joints showed the protein composition of the synovial effusion to be qualitatively similar to that of the serum (Fig. 7). Semiquantitative estimation of lowdensity lipoprotein (LDL) expressed in terms of apolipoprotein B (apo-B), in similar matched samples of serum and synovial fluid, was carried out by 1-dimensional ('rocket') electroimmunodiffusion. This showed a relatively constant proportion (3-5\%) of apo-B to be present in synovial fluid, as compared with serum, in both group A and group B animals. However, since the serum level of cholesterol and apo-B-containing lipoproteins was markedly raised in group B animals, this implied a high absolute concentration of these lipoproteins in the synovial effusion of the group.

On the other hand examination of smears of washed cells, from synovial effusions from the affected joints of group B animals by immunofluorescence by means of fluorescein-labelled antirabbit apo-B antiserum, only occasionally showed the presence of specific fluorescence within cells, which, when corresponding smears were stained with oil red $\mathrm{O}$, were seen to be crowded with lipid reactive with this stain. The significance of this observation is discussed later.

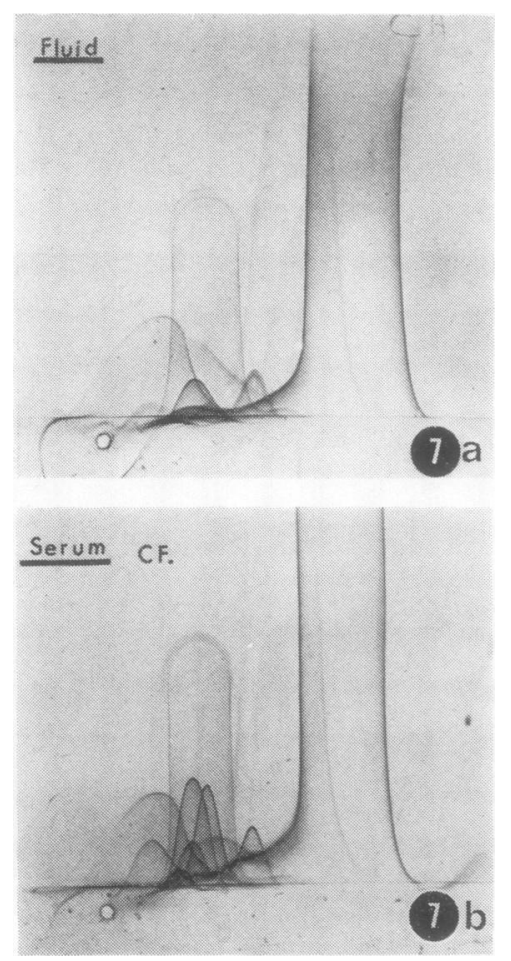

Fig. 7 Two dimensional crossed electrophoresis of (a) synovial fluid and (b) serum proteins of a group $B$ rabbit
Histological changes. None of the control (left) knee joints of either group of rabbits showed any evidence of acute inflammation. Nor was there any $\vec{\Rightarrow}$ evidence of lipid infiltration even in material from the

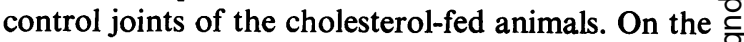
other hand the histological appearance of the injected joints of group A animals up to 14 days after $\vec{\nabla}$ challenge were characteristic of the acute phase of $\cong$ immune arthritis. The tissues were infiltrated by a $\infty$ variety of inflammatory cells including poly- $\overrightarrow{0}$ morphs, plasma cells, and other mononuclear cells, $\overrightarrow{\vec{J}}$ and occasional giant cells (Fig. 8). Villous hyper- $\vec{\omega}$ plasia was evident at 8 weeks and onwards, villous proliferation was more marked and aggregates of $\bar{\alpha}$ lymphoid cells were seen beneath the thickened $\omega_{0}^{\omega}$ synovial lining and around blood vessels. A dili- ir gent search revealed an occasional mononuclear cell containing scanty lipid droplets.

The histological picture of inflammatory response in the group B rabbits was closely similar except $\vec{\overrightarrow{ }}$ that lipid was seen on the surface of and within synovial cells. At 14 days and onwards intra- $\frac{0}{0}$ cellular lipid was distributed as small groups of $\mathbb{Z}$ 'foam cells' below the lining cells of the synovial $\overrightarrow{0}$ membrane (Fig. 9) and scattered throughout the thickness of the synovium. At 5 and 8 weeks increasin numbers of fat-filled cells formed groups and aggres gates resembling xanthomata (Fig. 10). By 14 weeks the deeper xanthoma-like clusters were surrounded by fibroblasts and strands of dense collagen.

Immunohistology. In relation to the heterologous antigen used to provoke the arthritis, using fluores-

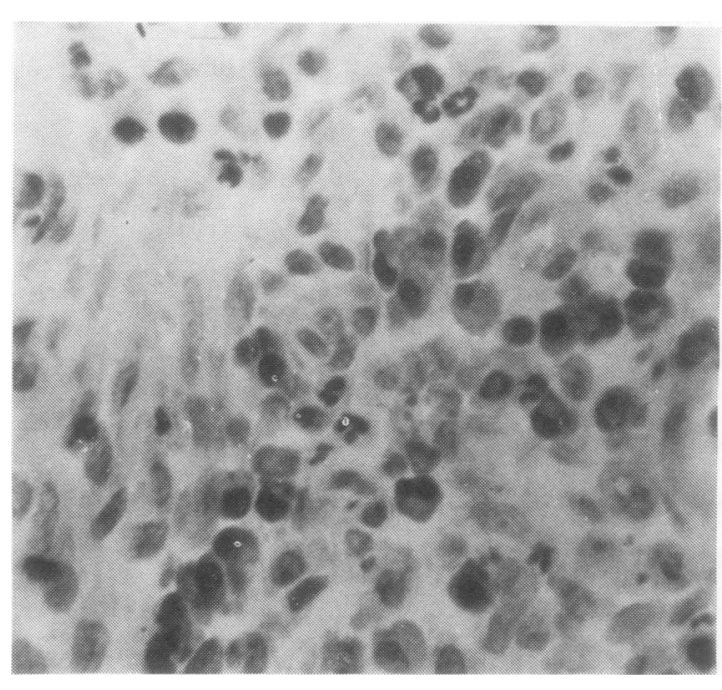

Fig. 8 Inflammatory cells in the synovial tissue from the antigen-injected joint of a group $A$ rabbit. (Haematoxylin and Eosin, $\times 250$ ) 
cein-labelled antiserum to this protein we found little or no evidence of persistence of human fibrinogen in sections from the injected joints of animals of either dietary group, even in material from

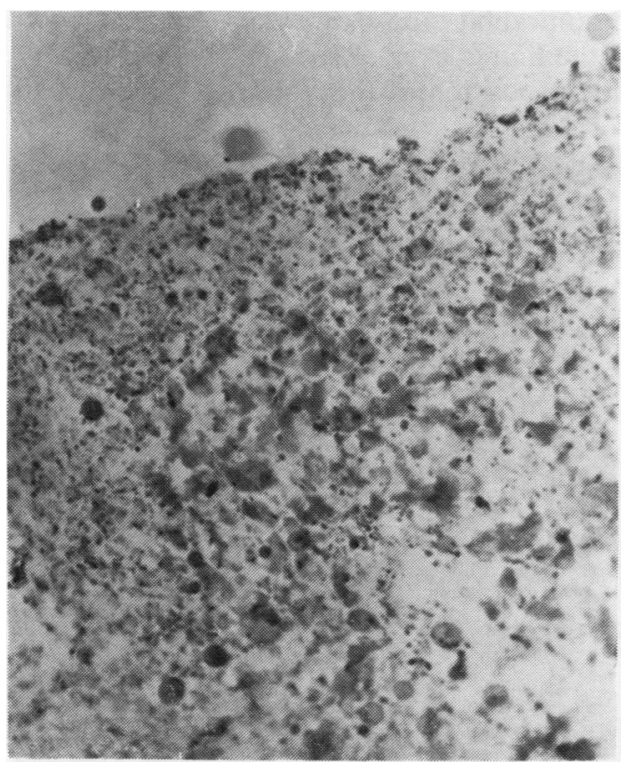

Fig. 9 Extracellular fat droplets and fat-filled cells in the synovial tissue of the antigen-injected joint of a group $B$ rabbit taken.14 days after the last intra-articular injection. (Oil red $O$ and light green, $\times 125$ )

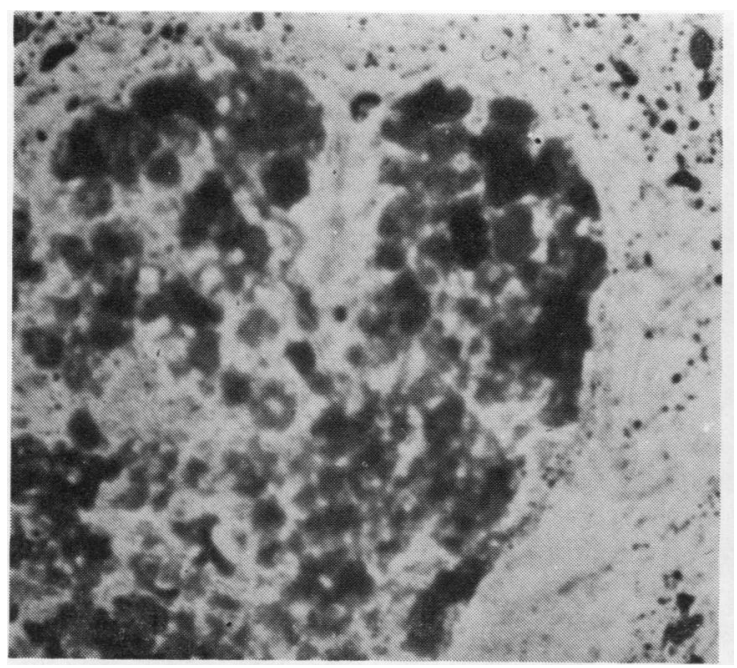

Fig. 10 Xanthomata-like structure in the synovial tissue from the injected joint of a group B rabbit taken 8 weeks after the last intra-articular injection. (oil red $\mathrm{O}$ and light green, $\times$ 125) rabbits killed within 1 day of intra-articular challenge.

The pattern of specific fluoresœnce seen in sections treated with fluorescein-labelled anti-rabbit IgG or antirabbit $\mathrm{C}^{\prime} 3$ proteins varied with the duration of induced arthritis in the affected joints of both groups of animals. In sections taken from animals killed within 1 or 4 days of intra-articular challenge intracellular specific fluorescence for IgG was seen in cells of the superficial and deeper layers of the synovial membrane (Fig. 11). A very similar pattern was seen in corresponding sections of the same tissue examined for C'3 (Fig. 12). In animals killed after 10 days specific fluorescence was seen as linear deposits

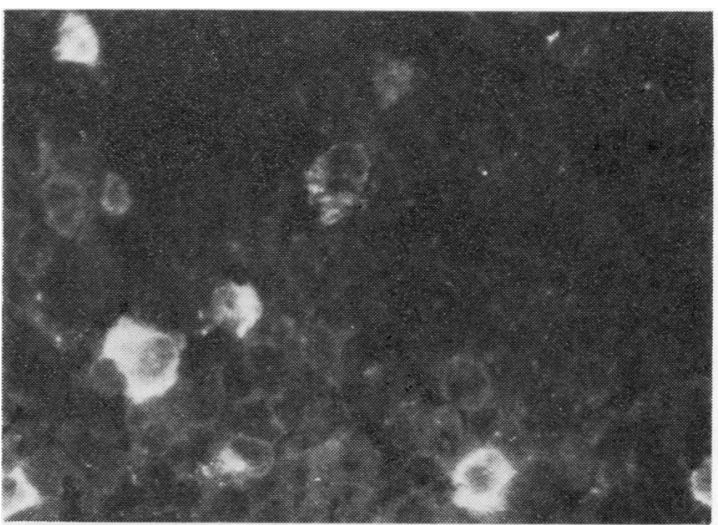

Fig. 11 IgG containing plasma cells and macrophages containing ingested immune complexes in.the synovial tissue from the injected joint of a group $\vec{A}$ rabbit taken 24 hours after the last intra-articular injection. (FITC guinea-pig antirabbit IgG, $\times 500$ )

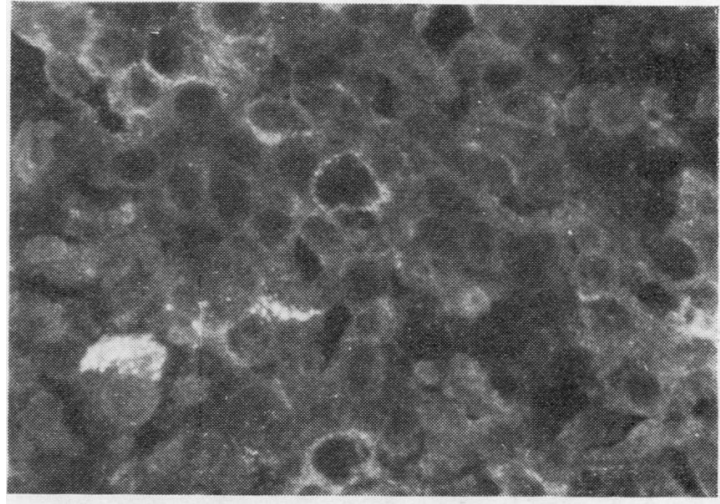

Fig. 12 Macrophages containing ingested immune complexes in the synovial tissue from the injected joint of a group $A$ rabbit taken 24 hours after the last intraarticular injection. (TMRITC guinea-pig anti-rabbit $\left.C^{\prime} 3, \times 500\right)$ 
and streaks on the surface or articular cartilage, menisci, and on collagenous intra-articular structures (Fig. 13a). A similar appearance of superficial deposition was seen with anti-C'3 (Fig. 13b). No specific staining of any kind was seen in the tissues from the control joints.

In areas corresponding to those seen in conventionally stained sections to contain clusters of lymphoid cells and plasma cells, sections treated with labelled antirabbit IgG revealed cells reacting with the antiserum to show cytoplasmic fluorescence and the general morphological characteristics of
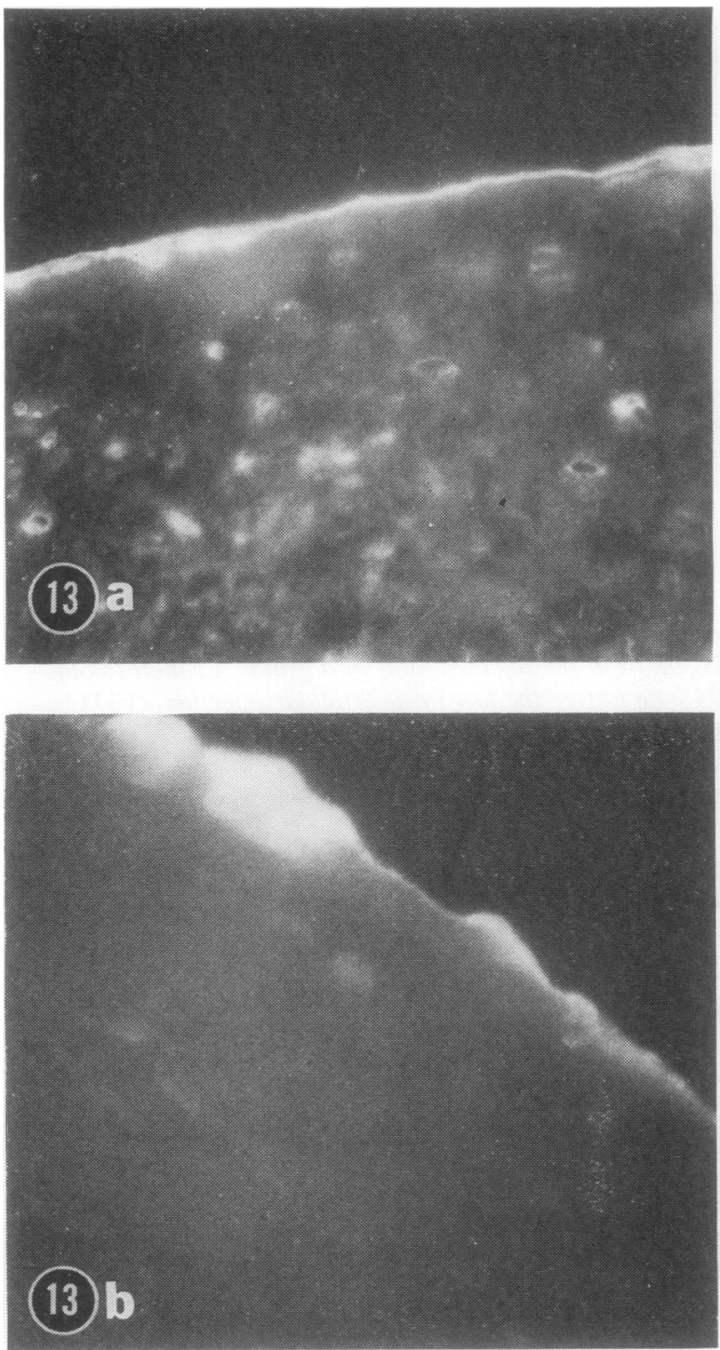

Fig. 13 Meniscus from the injected joint of a group $A$ rabbit. (a) FITC guinea-pig and antirabbit IgG $(\times 250)$; (b) TMRITC guinea-pig antirabbit $C^{\prime} 3(\times 250)$ typical plasma cells (Fig. 14). Many of these cells also bound human fibrinogen strongly (Fig. 15) when examined by indirect immunofluorescence.

On examining sections from the joints of all the group B rabbits after treatment with fluoresceinlabelled antirabbit apo-B we saw linear streaks beneath the lining layer of the synovial membrane, suggesting deposition of this antigen on the surface

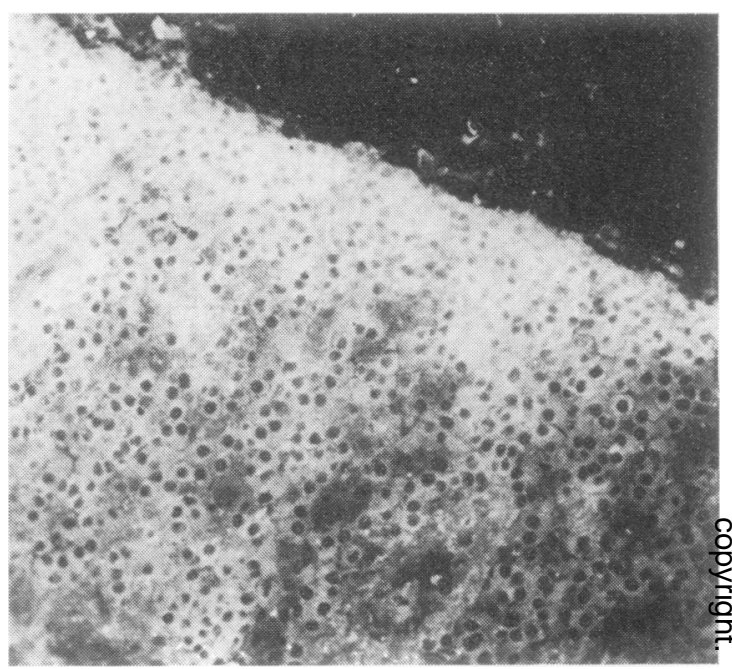

Fig. 14 IgG containing plasma cells in the synovial tissue of the injected joint of a group A rabbit taken 5 weeks after the last intra-articular injection. FITC guinea-pig antirabbit IgG $(\times 125)$

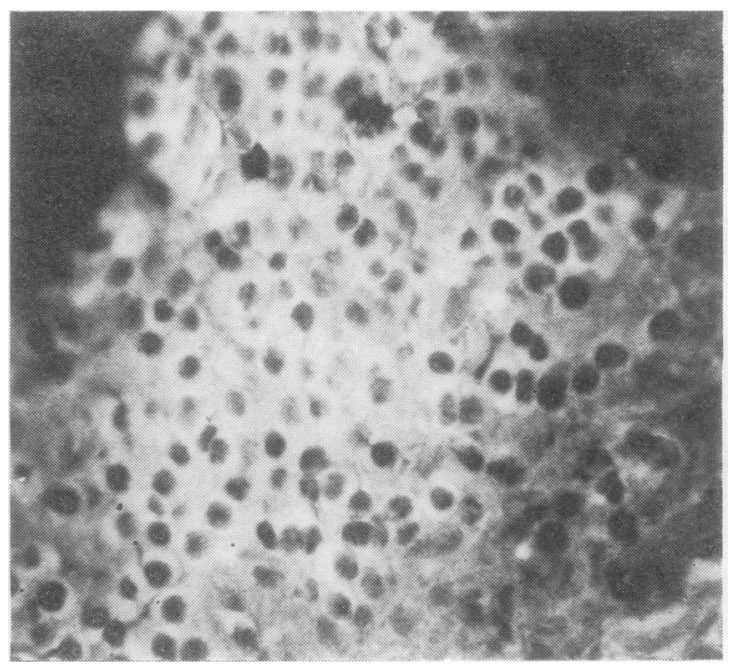

Fig. 15 Antihuman fibrinogen antibody-producing cells in the synovial tissue from the injected joint of a group $A$ rabbit taken 5 weeks after the last intra-articular injection (see 'Methods'). ( $\times 250)$ 
of collagen or in the interfibrillar matrix. In this material in contrast only occasional synovial lining cells showed specific fluorescence for the lipoprotein, and this was variable in intensity. In addition lipid staining and specific staining for apo-B were detected on the surface of articular cartilage, menisci, and other avascular collagenous intra-articular structures (Figs 16a and b).

These appearances were not seen in tissues taken from the affected joints of normolipidaemic rabbits or in tissues taken from the control joints of either group. It was also noticeable, in tissues from cholesterol-fed animals taken 10 days or more after induction of arthritis, that in areas where oil red $\mathbf{O}$ staining had revealed the presence of aggregates of fat-filled cells forming xanthoma-like clusters in the deeper portions of the synovial membrane (see Fig. 10), most of these fat-filled
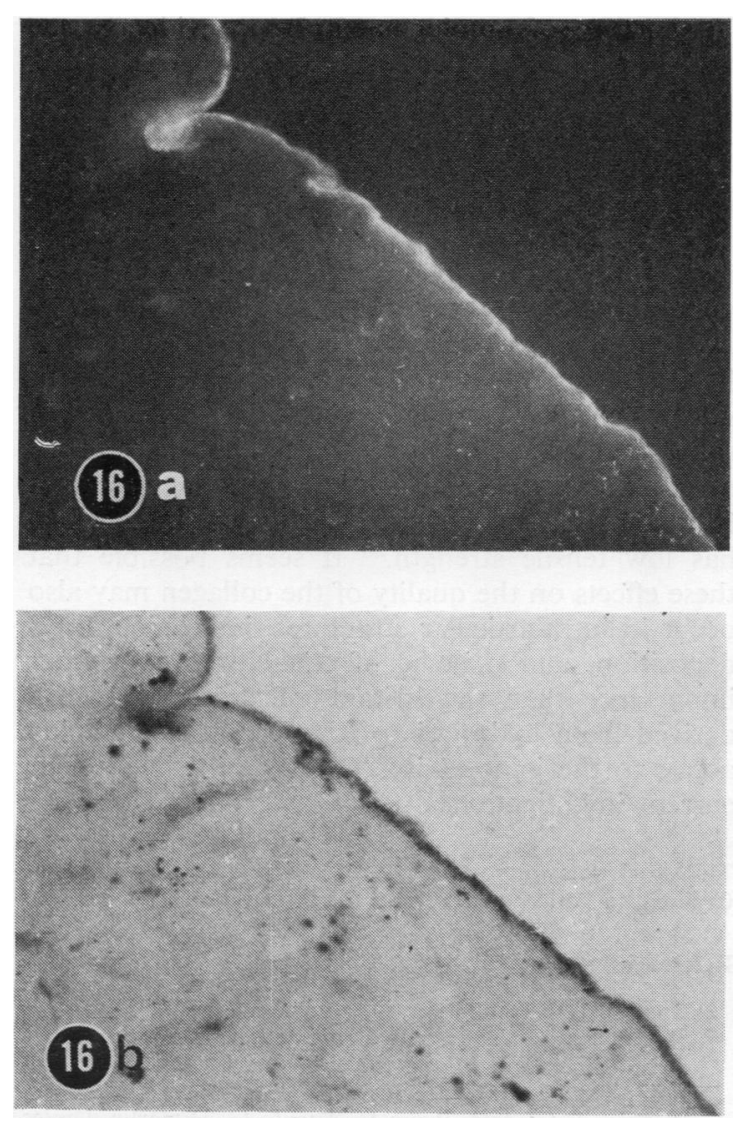

Fig. 16 Meniscus from the injected joint of a group $B$ rabbit. (a) FITC-guinea-pig antirabbit apo-B; (b) the same frozen section stained with oil red $O$ and light green $(\times 125)$ cells failed to react with the labelled anti-apo-B antiserum.

\section{Discussion}

The principal features of the immune arthritis elicited in our experiments correspond closely with those described by other workers who have used this animal model. ${ }^{414-17}$ In particular, we have confirmed the rapid disappearance of the provoking antigen from the joint; the subsequent evidence of sustained local intra-articular synthesis of specific antibody to this antigen; and the presence of antigen-antibody-complement complexes bound in the superficial layers of certain intra-articular structures-all these features occurring in association with a chronic arthritis resembling human rheumatoid arthritis in many respects. We have also confirmed the infrequent occurrence of serum antiglobulin (rheumatoid-factor-like) activity in this model, a feature perhaps distinguishing the model from human rheumatoid disease.

The induction in one group of our animals of concurrent hyperlipidaemia, and the experimental design in which arthritis was induced on one side only (ensuring that each animal served as its own control in relation to challenged and unchallenged joints), allow certain additional observations to be made.

For example, in relation to the topographic distribution of lesions it is noteworthy that the apo-B-containing lipoprotein $(\mathrm{LpB})$ of the cholesterol-fed rabbits consists of large macromolecules which are mainly confined to the circulation but which can be shown to 'leak' into the extravascular compartment at sites of altered vascular permeability. ${ }^{5}$

Where transudation of $\mathrm{LpB}$ molecules occurs into the connective tissue in hyperlipidaemic humans or animals and where lipid reactive with fat stains is demonstrably bound to connective tissue elements, apo-B is also present in a precisely similar distribution. This identity of distribution between lipid 'staining' and immunochemical reaction for apo-B has been interpreted as indicative of the presence of the intact lipoprotein molecule at such sites. $^{5}$

In contrast, fat-filled cells in connective tissues react variably with fluorescein-labelled anti-apo-B, some cells reacting brightly, others weakly, and some failing to react. It has been suggested that full immunoreactivity in such cells is compatible with the uptake of intact lipoprotein by phagocytosis; whereas relative lack, or loss of immunoreactivity, is due to progressive degradation and modification of the ingested lipoprotein molecules by intracellular enzymatic processes. It has also been proposed that, 
after digestion of the apolipoprotein, the lipid residue may be further modified by cholesterol esterification and contributed to by local lipid synthesis of triglyceride and phospholipid. ${ }^{5}$

In the light of the above considerations, the following conclusions can be drawn. (i) The presence of lipid in intra-articular structures in this model derives initially from plasma lipoproteins, though the lipid residues may subsequently undergo modification. (ii) The occurrence of lipid (lipoprotein) in the arthritic joint suggests that marked local increase of vascular permeability must occur in the challenged joint to allow permeation of the macromolecular lipoprotein into the joint cavity. There is evidence for similar alteration of permeability in human arthritic conditions. ${ }^{1819}$ (iii) The severity and extent of lipid (lipoprotein) infiltration of the joint appears to reflect the severity of the hyperlipidaemia in that heavy tissue deposits were easily demonstrable in the affected joint of the hyperlipidaemic animals, whereas only an occasional lipid droplet was found in the tissues of the affected joints of normolipidaemic rabbits; (iv) Synovial cells of the type A variety are known to be actively phagocytic and the presence of abundant lipid in many of the cells in situ in the synovial lining, suggested uptake of lipid and lipoprotein by these cells. (v) Intact $\mathrm{LpB}$, on the other hand, was identified on the surface of connective tissues beneath the lining layer of synovial cells in the synovial membrane and the superficial layers of menisci, articular cartilage, and intra-articular ligaments. Firm binding of intact $\mathrm{LpB}$ has been shown to occur selectively to elements of the ground substance or to fibres of the connective tissues elsewhere in hyperlipidaemic animals and in man, ${ }^{20}$ possibly via interaction of LpB with the glycosaminoglycans or proteoglycans of these tissues.

The lipid residues, and in particular crystalline cholesterol and cholesterol esters deposited intraarticularly, appear to persist for relatively long periods. For example, free cholesterol crystals were identified in the affected joint of an animal killed 9 months after the induction of arthritis and hyperlipidaemia. Crystalline cholesterol and its esters are known to be markedly irritant and sclerogenic when implanted in connective tissues. ${ }^{21}$ It seems possible therefore, that the cholesterol found in joint effusions in human rheumatic sufferers with concurrent hyperlipidaemia also originates from plasma lipoproteins insuding into inflamed joints as previously suggested, ${ }^{3}$ and that cholesterol crystals, so derived, contribute nonspecifically to the maintenance of chronic inflammation in the joint.

Recent work ${ }^{22}$ suggests that persistence of 'undigested' antigen (as bound immune complexes) in the joint is not in itself the crucial factor responsible for the persistence of immune arthritis. Nevertheless, the topographic distribution of the immune complex deposition may still be determined by the initial acute inflammation in the joint, which probably causes not only increase of vascular permeability but also increase in the permeability of the connective tissue gel of intra-articular structures. This latter change would account for the permeation of immune complexes and lipoprotein molecules in the joint fluid into the superficial layers of these structures.

The chondromucoproteins of cartilage form insoluble complexes in vitro with $\mathrm{LpB},{ }^{23}$ making this a possible mechanism for the entrapment of the lipoprotein in articular cartilage and menisci. Electron microscopic observations made on this model $^{24}$ suggest permeation of intra-articular structures by preformed immune complexes rather than trapping of antigen by pre-existing antibody. ${ }^{1725}$ In the case of autologous $\mathrm{LpB}$ no evidence was obtained of the formation of autoantibodies to the lipoprotein to account for an immunological mechanism for its entrainment in joint structures.

In the arterial wall it has been shown that $\mathrm{LpB}$ molecules bound to fibrous tissue are demonstrable not only on the outer surface of bundles of collagen microfibrils but also along the course of individual microfibrils within the bundle. ${ }^{20} \mathrm{LpB}$ binding is attended both by increased collagen synthesis ${ }^{26}$ and by significant qualitative changes in this type of normal collagen formed. ${ }^{27}$ On the other hand in some circumstances 'abnormal' polymorphic forms of collagen are also detectable. Among these is a form known as fibrous long spacing collagen, which has low tensile strength. ${ }^{28}$ It seems possible that these effects on the quality of the collagen may also occur in intra-articular structures, induced by $\mathrm{LpB}$ deposition, and may be of equal or even greater importance than the irritant effect of cholesterol derived from hydrolysis of the lipoprotein gaining access to the joint cavity. This hypothesis is under current investigation.

This work was supported by the Arthritis and Rheumatism Council, to which our grateful thanks are due.

\section{References}

1 Rooney P J, Ballantyne D, Buchanan W W. Disorders of the locomotor system associated with abnormalities of lipid metabolism and the lipoidoses. Clin Rheum Dis 1975; 1: 163-93.

2 Rondier J, Cayla J, Roux H, Turpin G. Hyperlipidémies et manifestations de la sphère rhumatologique. Sem Hop Paris 1979; 53: 813-22.

3 Zuckner J, Uddin J, Gantner G E, Dorner R W. Cholesterol crystals in synovial fluid. Ann Intern Med 1964; 60: $436-46$. 
4 Dumonde D C, Glynn L E. The production of arthritis in rabbits by an immunological reaction to fibrin. Brit $J$ Exp Pathol 1962; 43: 373-83.

5 Walton K W, Thomas C, Dunkerley D. J The pathogenesis of xanthomata. J Pathol 1973; 109: 271-88.

6 Pearson S, Stern S, McGavack T H. A rapid, accurate method for the determination of total cholesterol in serum. Anal Chem 1953; 25: 813-4.

7 Hawker R J, Hawker L M. A rapidly produced ${ }^{125}$ Ilabelled autologous fibrinogen: In vitro properties and preliminary metabolic studies in man. $J$ Clin Pathol 1976; 29: 495-501.

8 Herbert W J. Passive haemagglutination. In Weir D M, ed. Handbook of Experimental Immunology. Oxford: Blackwell, 1967: 720-44.

9 Rose H M, Ragan C, Pearce E, Lipman M O. Differential agglutination of normal and sensitised sheep erythrocytes by sera of patients with rheumatoid arthritis. Proc Soc Exp Biol NY 1948; 68: 1-6.

10 Propp R P, Alper C A. Rabbit $\mathrm{C}_{3}$ : Isolation and characterization of reactions in vitro and during in vivo antigenantibody interaction. Immunology 1969; 17: 695-707.

11 Stanworth D R. A rapid method of preparing pure serum gamma-globulin. Nature 1960; 188: 156-7.

12 Nairn R C. Fluorescent Protein Tracing, 3rd ed. Edinburgh: Livingstone, 1969.

13 Laurell C B. Antigen-antibody crossed electrophoresis. Anal Biochem 1965; 10: 358-61.

14 Glynn L E. The chronicity of inflammation and its significance in rheumatoid arthritis. Ann Rheum Dis 1968; 27: 105-21.

15 Glynn L E. Experimental'models and etiology of inflammatory rheumatic diseases. Scand $J$ Rheumatol 1976; 5: Suppl. 12: 55-62.

16 Cooke T D, Hurd E R, Ziff M,'Jasin H E. The pathogenesis of chronic inflammation in experimental antigeninduced arthritis. II. Preferential localisation of antigenantibody complexes to collagenous tissues. J Exp Med 1972; 135: 323-38.
17 Hollister J R, Mannik M. Antigen retention in joint tissues in antigen-induced synovitis. Clin Exp Immunol 1974; 16: 615-27.

18 Kushner I, Somerville J A. Permeability of human synovial membranes to plasma proteins: Relationship to molecular size and inflammation. Arthritis Rheum 1971; 14: 560-70.

19 Simkin P A. Synovial permeability in rheumatoid arthritis. Arthritis Rheum 1979; 22: 689-96.

20 Walton K W, Morris C J. Studies on the passage of plasma proteins across arterial endothelium in relation to atherosclerosis. Prog Biochem Pharmacol 1977; 13: 138-52.

21 Adams C W M. Vascular Histochemistry in relation to the Chemical and Structural Pathology of Cardiovascular Disease. London: Lloyd-Luke, 1967; 160-5.

22 Fox A, Glynn L E. Is persisting antigen responsible for the chronicity of experimental allergic arthritis? Ann Rheum Dis 1977; 36: 34-8.

23 Anderson A J. The formation of chondromucoproteinfibrinogen and chondromucoprotein- $\beta$-lipoprotein complexes. Biochem J 1963; 88: 460-9.

24 Ishikawa H, Smiley J D, Ziff M. Electron-microscopic demonstration of immunoglobulin deposition in rheumatoid cartilage. Arthritis Rheum 1975; 18: 563-76.

25 Jasin H E. Mechanism of trapping of immune complexes in joint collagenous tissues. Clin Exp Immunol 1975; 22: 473-85.

26 McCullagh K G, Ehrhardt L A. Increased collagen synthesis in experimental canine atherosclerosis. Atherosclerosis 1974 ; 19: 13-28.

27 McCullagh K G, Ehrhart L A. Induction of Type I and repression of Type III collagen synthesis in experimental canine atherosclerosis. Circulation 1976; 54: Suppl. II: 85.

28 Morris C J, Bradby G V R, Walton K W. Fibrous longspacing collagen in human atherosclerosis. Atherosclerosis 1978 ; 31 : 345-54. 